\title{
PROFIL PENGETAHUAN DAN KEYAKINAN VAKSINASI HPV SEBAGAI UPAYA PENCEGAHAN KANKER SERVIKS PADA MAHASISWI DI UNIVERSITAS AIRLANGGA, SURABAYA
}

\author{
Ajeng D. Sari ${ }^{1)}$, Nabilah Lutfi ${ }^{1)}$, Hudiya Syadida ${ }^{1)}$, Dirani ${ }^{1)}$, Nurul Cholifah ${ }^{1)}$, Tiara P. Asriningrum ${ }^{1)}$, Pertiwi K. \\ Yekti $^{1)}$, Binati ${ }^{1)}$, Intan A. Cahyasari ${ }^{1)}$, Nur S. Hidayatullah ${ }^{1)}$, Lia A. Mulya ${ }^{1)}$, Akbar T. Firman ${ }^{1)}$, Gesnita \\ Nugraheni ${ }^{1)}$ \\ 1) Fakultas Farmasi, Universitas Airlangga \\ Jl. Dharmawangsa Dalam Surabaya 60286 \\ E-mail: ajeng.della.sari-2015@ff.unair.ac.id
}

\begin{abstract}
ABSTRAK
Kanker serviks merupakan pembunuh wanita nomor satu di Indonesia dengan angka kejadian 50\% dari 15.000 kasus penderita meninggal dunia. Penyebab utama dari kanker serviks ini adalah HPV (Human Papilloma Virus) serta beberapa faktor resiko lain. Pencegahan primer kanker serviks dapat dilakukan dengan vaksinasi HPV. Pengetahuan tentang kanker serviks masih rendah sehingga hal ini mempengaruhi keyakinan remaja putri dalam melakukan vaksinasi HPV. Penelitian ini bertujuan untuk menganalisis profil pengetahuan dan keyakinan vaksinasi HPV pada mahasiswi di Universitas Airlangga Surabaya dengan menggunakan teori Health Belief Model (HBM). Metode pengambilan sampel yang digunakan adalah kuota non random sampling sehingga digunakan sejumlah 120 sampel yang berstatus mahasiswi dari fakultas kesehatan dan non kesehatan di Universitas Airlangga Surabaya. Sebanyak 70,8\% mahasiswi dikategorikan menjadi kelompok dengan nilai pengetahuan yang tinggi, namun pengetahuan tidak signifikan mempengaruhi niat untuk melakukan vaksinasi HPV. Pada teori HBM, keyakinan responden untuk melakukan vaksinasi HPV sebanyak 90,8\% memiliki persepsi yang tinggi terhadap persepsi keseriusan dan 92,5\% terhadap persepsi manfaat yang didapatkan setelah melakukan vaksinasi HPV. Adanya dukungan keluarga menunjukkan hubungan yang signifikan mempengaruhi niat untuk melakukan vaksinasi HPV $(\mathrm{p}<0,05)$. Maka, upaya peningkatan pengetahuan dan keyakinan perlu dilakukan untuk mahasiswi beserta keluarga agar niat melakukan vaksinasi HPV meningkat.
\end{abstract}

Kata kunci: Kanker Serviks, Vaksinasi HPV, Pengetahuan, Keyakinan, Health Belief Model

\begin{abstract}
Cervical cancer is the number one killer disease in women in Indonesia with the $50 \%$ mortality of 15.000 cases. The main cause of cervical cancer is HPV (Human Papilloma Virus) and other risk factors. Primary prevention of cervical cancer is HPV vaccination. Knowledge about cervical cancer is still low, thus affect belief of female college students to do HPV vaccination. The aim of this research is to analyse knowledge profile and belief in HPV vaccination in female college students in Universitas Airlangga Surabaya using Health Belief Model Theory. Non random and quota sample is used as sampling method. Participants are 120 female college students from health and non-health faculties of Universitas Airlangga Surabaya. Approximately 70,8\% (n=85) participants are categorized as group with high score of knowledge, but knowledge is not significantly affect intention to do HPV vaccination. In HBM theory, 90,8\% $(n=109)$ participants have high perception in perceived severity and $92,5 \%(n=111)$ participants in perceived benefit after getting HPV vaccination. The presence of family support showed significant correlation affecting the intention to do HPV vaccination $(\mathrm{p}<0,05)$. Therefore, effort to increase knowledge and belief for college students and their family is needed in order to increase the intention to do HPV vaccination.
\end{abstract}

Keywords: Cervical Cancer, HPV Vaccination, Knowledge, Belief, Health Belief Model 


\section{PENDAHULUAN}

Kanker serviks merupakan penyakit ginekologik yang memiliki tingkat keganasan cukup tinggi dan menjadi penyebab kematian utama akibat kanker pada wanita di negara-negara berkembang. Pada kanker serviks menunjukkan adanya sel-sel abnormal yang terbentuk oleh sel-sel jaringan yang terus menerus dan tidak terbatas pada bagian leher rahim (Fitriana dan Ambarini, 2012). Penyebab utama dari kanker serviks ini adalah infeksi Human Papilloma Virus (HPV) serta beberapa perilaku seksual dan reproduksi individu, seperti berhubungan seksual pada usia muda, berganti-ganti pasangan dalam berhubungan seksual, merokok, serta tingkat kebersihan individu yang rendah terutama pada organ genital (Fitriana dan Ambarini, 2012). Virus Human papilloma berkontribusi terhadap 20\% kematian akibat kanker di negara berpenghasilan rendah dan menengah. Kasus kanker serviks dinyatakan sebagai jenis kanker kedua terbanyak yang menyerang wanita di seluruh dunia setelah kanker payudara. Pada tahun 2012 diperkirakan terdapat sekitar 528.000 kasus baru dan 266.000 kematian akibat kanker serviks, dan sekitar $85 \%$ kasus terjadi di negara berkembang (Sari dan Syahrul, 2014). Lebih dari 60\% kasus baru dan sekitar $70 \%$ kematian akibat kanker di dunia setiap tahunnya terjadi di Afrika, Asia, Amerika Tengah dan Selatan. Diperkirakan kasus kanker tahunan akan meningkat dari 14 juta pada 2012 menjadi 22 juta dalam dua dekade berikutnya (Kementerian Kesehatan RI Pusat Data dan Informasi Kesehatan, 2015). International Agency For Research On Cancer (IARC) telah memperkirakan pada tahun 2050 populasi perempuan usia 15 tahun ke atas yang menderita kanker serviks di seluruh dunia mencapai tiga miliar (Marlina et al., 2016).

Indonesia merupakan negara kedua di dunia setelah Cina yang memiliki pengidap kanker serviks terbanyak dengan angka kejadian mencapai 15.000 kasus setiap tahun dan 50\% dari penderita meninggal dunia (Yayasan Kanker Indonesia, 2017). Hal ini membuat kanker serviks dinyatakan sebagai penyakit pembunuh wanita nomor 1 di Indonesia karena setiap harinya dari 40 wanita yang terdiagnosa menderita kanker serviks, 20 wanita diantaranya meninggal karena kanker serviks (Nurlaila et al., 2016). Wanita berusia diatas 15 tahun merupakan populasi beresiko tinggi terkena kanker serviks dan kelompok usia terbanyak yang menderita kanker serviks adalah wanita usia 25-64 tahun (ICO, 2018). Selain itu, kejadian kanker serviks sangat mempengaruhi kualitas hidup dari penderita dan keluarganya. Kanker serviks juga akan sangat mempengaruhi sektor pembiayaan kesehatan oleh pemerintah. Oleh sebab itu, peningkatan upaya penanganan kanker serviks terutama dalam bidang pencegahan dan deteksi dini sangat diperlukan karena kanker serviks dapat menyebabkan infertilisasi, morbiditas, dan mortalitas terhadap wanita. Program nasional pencegahan kanker serviks yang sudah dilaksanakan saat ini adalah deteksi dini kanker leher rahim dengan metode Inspeksi Visual Asam Asetat (IVA). Pencegahan kanker leher rahim akan semakin efektif jika bersamaan dengan melakukan upaya proteksi spesifik. Berdasarkan Keputusan Menteri Kesehatan RI Nomor 34 tahun 2015, saat ini pencegahan primer telah digalakkan yaitu menghindari resiko dan vaksinasi HPV.

Vaksinasi HPV merupakan bentuk perlindungan spesifik terhadap kanker serviks yang diberikan pada saat belum terinfeksi dan memiliki tingkat perlindungan yang sangat efektif terhadap $70 \%$ kasus potensial kanker serviks karena menargetkan tipe HPV 16 dan 18 (WHO, 2017). Berdasarkan beberapa penelitian menggunakan vaksin bivalent dan quadrivalent menunjukkan bahwa efektivitas kedua vaksin cukup tinggi dalam mencegah dari infeksi HPV tipe 16 dan tipe 18 serta infeksi tipe 6 dan 11 yang dapat menyebabkan genital warts atau kondiloma akuminata. Efektivitas vaksin bivalen mencapai lebih dari $90 \%$ setelah pemberian dosis ketiga pada wanita sedangkan efektivitas vaksin quadrivalent diperkirakan antara $70-100 \%$ dan diperkirakan dapat mengurangi insidensi kasus kanker serviks sampai 90\% (Radji, 2009). Rekomendasi usia untuk vaksinasi HPV agar diperoleh hasil yang efektif yaitu pada wanita usia 9-13 tahun (WHO, 2017). Selain itu vaksin juga direkomendasikan untuk diberikan pada umur 1326 tahun yang tidak mendapat pengulangan vaksin atau tidak mendapatkan vaksin secara lengkap (Setiawati, 2014). Namun, hasil penelitian memperlihatkan vaksin HPV masih memberikan manfaat apabila diberikan pada wanita sampai usia 55 tahun. Menurut Ikatan Dokter Anak Indonesia (IDAI) dan Persatuan Dokter Penyakit Dalam Indonesia (PAPDI), untuk anak dan remaja vaksinasi dapat diberikan sejak usia 10 hingga 18 tahun sedangkan untuk usia dewasa vaksinasi HPV dapat diberikan pada usia 19-55 tahun (Sari dan Syahrul, 2014).

Pemerintah mencanangkan program imunisasi nasional yaitu vaksin HPV kepada siswi perempuan kelas 5 (dosis pertama) dan 6 (dosis kedua) SD/MI dan sederajat baik negeri maupun swasta melalui program Bulan Imunisasi Anak Sekolah (BIAS). Saat ini, diketahui 67 dari 194 negara di dunia yang sudah mengimplementasikan program imunisasi HPV di negaranya dan banyak hasil dari penelitian yang sah dari negara-negara tersebut menunjukan manfaat yang bermakna untuk menurunkan beban penyakit kanker serviks serta penyakit terkait infeksi HPV lainnya (WHO, 2016). 
Program vaksinasi HPV untuk remaja putri telah disetujui sejak tahun 2006 (Wals et al., 2008). Tetapi pada implementasinya mengalami hambatan dari biaya vaksin, subjek penerimaan dan kurangnya kesadaran (Agosti et al., 2007). Keberhasilan program vaksinasi HPV akan dibutuhkan kesadaran tentang penyakit terkait HPV dan manfaat vaksinasi untuk remaja (Brewer dan Fazekas, 2007).

Pada perempuan berusia 18 hingga 26 tahun telah memiliki resiko untuk mengalami kanker serviks. Hal tersebut menandakan bahwa perempuan usia produktif harus mulai memperhatikan kesehatan reproduksinya. Proses pendidikan formal maupun non formal serta adanya peran media massa seharusnya telah mempermudah dalam mengakses informasi kesehatan dan membuka wawasan remaja perempuan. Namun, kurangnya perhatian dan pemanfaatan fasilitas secara tepat menyebabkan kurangnya pengetahuan tentang bahaya, cara penyebaran, dan khususnya pencegahan terhadap infeksi tersebut sehingga angka kejadian dan kematian akibat infeksi HPV masih meningkat secara signifikan. Berdasarkan hasil penelitian tentang gambaran pengetahuan dan perilaku vaksinasi HPV menunjukkan sebanyak $8,4 \%$ responden memiliki pengetahuan baik tentang kanker serviks, $16,9 \%$ responden memiliki pengetahuan baik tentang vaksin HPV. Lebih dari $50 \%$ responden memiliki sikap negatif terhadap kanker serviks dan vaksinasi HPV serta 64,3\% responden memiliki perilaku baik terhadap pencegahan kanker serviks. Hal tersebut mempengaruhi perilaku melakukan vaksinasi HPV. Jumlah responden yang belum melakukan vaksinasi HPV adalah 92,2\% (Dethan dan Suariyani, 2017).

Teori HBM merupakan salah satu model pertama yang dirancang untuk mendorong masyarakat dalam melakukan tindakan ke arah kesehatan yang positif (Ekowati et al., 2017). Dalam perkembangannya, terdapat empat konstruk utama dalam teori HBM yakni perceived susceptibility, perceived severity, perceived benefit dan perceived barriers. Berdasarkan uraian tersebut, penelitian ini bertujuan untuk menganalisis profil pengetahuan dan keyakinan melakukan vaksinasi HPV sebagai upaya mencegah penyakit kanker serviks secara dini pada wanita. Dalam hal ini, HBM merupakan teori pertama di bidang kesehatan yang penggunaanya dapat menjelaskan perilaku pencegahan dan respon individu terhadap penyakit (Setiyaningsih et al., 2016). Teori HBM didasarkan pada kepercayaan bahwa perilaku individu ditentukan oleh persepsi kerentanan dari kanker serviks, persepsi keseriusan dari kanker serviks, persepsi manfaat dari vaksinasi HPV dan persepsi hambatan dari vaksinasi HPV. Persepsi yang dirasakan individu tersebut dipengaruhi faktor pemodifikasi yang secara tidak langsung dapat mempengaruhi perilaku kesehatan (Ekowati et al., 2017). Tujuan dari penelitian ini adalah untuk mengetahui status vaksinasi HPV, niat vaksinasi HPV serta menganalisis profil demografi, pengetahuan dan keyakinan vaksinasi HPV pada mahasiswi di Universitas Airlangga Surabaya dengan menggunakan teori Health Belief Model serta mengidentifikasi faktor yang berhubungan dengan niat melakukan vaksinasi HPV.

\section{METODE PENELITIAN}

Penelitian ini termasuk jenis penelitian analitik observasional dengan metode accidental sampling dan pendekatan cross sectional. Populasi penelitian ini adalah mahasiswi semua jenjang di Universitas Airlangga Surabaya yang berusia 18-26 tahun dan belum menikah. Pengambilan sampel berdasarkan teknik kuota non random sampling dengan jumlah sampel sebesar 120 responden. Sampel yang dipilih berasal dari fakultas kesehatan dan non kesehatan dengan proporsi masing-masing $50 \%$.

Lokasi penelitian dilakukan di kampus A, B, dan C Universitas Airlangga Surabaya. Teknik pengumpulan data menggunakan metode survei. Data primer diperoleh dari pengisian kuesioner yang terdiri dari jenis pertanyaan kombinasi tertutup dan terbuka. Tipe ini dipilih untuk memudahkan responden dalam memahami pertanyaan. Variabel terikat dalam penelitian ini adalah niat vaksinasi HPV dan variabel bebas meliputi pengetahuan, usia, pendapatan orang tua, dukungan keluarga, persepsi kerentanan, persepsi keseriusan, persepsi manfaat, persepsi hambatan dalam penerimaan vaksinasi HPV.

Pada penelitian ini, teori HBM yang digunakan meliputi perceived susceptibility, perceived severity, perceived benefit dan perceived barrier yang akan dilakukan analisis untuk mengetahui pengaruhnya terhadap niat vaksinasi HPV. Analisis data deskriptif dan analisis lain seperti uji hubungan dilakukan menggunakan metode t-test pada IBM SPSS Statistics 21 .

\section{HASIL DAN PEMBAHASAN \\ 1. Gambaran Demografi}

Hasil penelitian yang telah dilakukan terhadap 120 responden didapatkan data demografi sebagaimana ditunjukkan pada Tabel 1. Usia responden dengan rata-rata 20 tahun dan semua responden yang terlibat belum melakukan vaksinasi HPV. Persentase terbesar pendapatan orang tua adalah Rp500.000-3.000.000 yaitu sebesar 39,2\%. Dari semua responden, sebanyak $77,5 \%$ mendapat dukungan keluarga, namun hanya $35,8 \%$ yang 
mempunyai kemauan untuk melakukan vaksinasi HPV.

Tabel 1. Demografi Responden $(n=120)$

\begin{tabular}{lcc}
\hline \hline \multicolumn{2}{c}{ Demografi } & \multicolumn{1}{c}{$\mathbf{n}(\%)$} \\
\hline Usia (tahun) & $18-20$ & $66(55,0 \%)$ \\
\cline { 2 - 3 } & $21-23$ & $47(39,2 \%)$ \\
\cline { 2 - 3 } & $24-26$ & $7(5,8 \%)$ \\
\hline Pendapatan & $<500.000$ & $4(3,3 \%)$ \\
\cline { 2 - 3 } orang tua & $500.000-$ & $47(39,2 \%)$ \\
& 3.000 .000 & \\
\cline { 2 - 3 } & 3.000 .000 & $32(26,7 \%)$ \\
& 5.000 .000 & $37(30,8 \%)$ \\
\cline { 2 - 3 } Status & $>5.000 .000$ & $0(0 \%)$ \\
Vaksinasi & Sudah & 120 \\
\cline { 2 - 3 } & Belum & $43(35,8 \%)$ \\
\hline Niat & Ada & $77(64,2 \%)$ \\
Vaksinasi & Tidak ada & \\
\hline Dukungan & Ada & \\
Keluarga & & \\
\hline \hline
\end{tabular}

Dari hasil yang diperoleh, keinginan mahasiswi untuk melakukan vaksinasi lebih rendah $(35,8 \%)$ jika dibandingkan dengan penelitian yang dilakukan pada 845 mahasiswi di Taiwan $(57,4 \%)$ (Hsu et al., 2009). Penelitian tentang niat vaksinasi juga dilakukan pada 256 mahasiswi di Amerika Serikat, hasilnya sebanyak $41 \%$ mahasiswi berniat untuk melakukan vaksinasi HPV (Patel et al., 2012). Dengan rendahnya keinginan vaksinasi dari hasil penelitian ini, maka diperlukan upaya promosi kesehatan untuk meningkatkan keinginan mahasiswi untuk melakukan vaksinasi HPV.

\section{Pengetahuan}

Tingkat pengetahuan responden mengenai vaksin HPV dapat dilihat pada Tabel 2, yang terdiri dari 7 pernyataan yang diajukan pada responden mengenai pengetahuan secara umum tentang kanker serviks dan vaksinasi HPV. Jawaban dari responden selanjutnya dilakukan pengelompokkan tingkat pengetahuan yang menggunakan kriteria skor pada Tabel 3. Dari 120 responden, 67 (55,8\%) responden tidak mengetahui penyebab kanker serviks. Sebanyak $112(93,3 \%)$ responden mengetahui Papanicolaou (PAP) test dapat digunakan untuk mengetahui kanker serviks, $(86,7 \%)$ mengetahui HPV dapat ditularkan melalui hubungan seksual, 61,7\% mengetahui infeksi HPV tidak dapat diobati dengan antibiotik, 99,2\% mengetahui vaksinasi HPV dapat mencegah kanker serviks, 63,3\% mengetahui vaksinasi HPV dianjurkan pada wanita dan laki-laki, dan 54,2\% mengetahui tidak semua tipe HPV menyebabkan kanker. Mayoritas responden (70,9\%) memiliki tingkat pengetahuan yang tinggi. Rata-rata skor pengetahuan pada responden dari fakultas kesehatan lebih tinggi $(75,4 \%)$ dibanding dengan mahasiswi dari fakultas non-kesehatan (68\%) dan skor rata-rata total pengetahuan adalah $71,4 \%$ $(\mathrm{p}=0,012)$.

Tabel 2. Profil Pengetahuan tentang Kanker Serviks dan HPV

\begin{tabular}{|c|c|c|}
\hline \multirow[t]{2}{*}{ Pernyataan } & \multicolumn{2}{|c|}{ n (\%) } \\
\hline & $\begin{array}{c}\text { Jawaban } \\
\text { Benar }\end{array}$ & $\begin{array}{c}\text { Jawaban } \\
\text { Salah }\end{array}$ \\
\hline $\begin{array}{ll}\text { Penyebab } & \text { kanker } \\
\text { serviks } & \text { adalah } \\
\text { bakteri } & \\
\end{array}$ & $53(44,2 \%)$ & $67(55,8 \%)$ \\
\hline $\begin{array}{lr}\text { Kanker } & \text { serviks } \\
\text { dapat } & \text { diketahui } \\
\text { dengan } & \text { PAP test }\end{array}$ & $112(93,3 \%)$ & $8(6,7 \%)$ \\
\hline $\begin{array}{lr}\text { Penularan } & \text { HPV } \\
\text { dapat } & \text { melalui } \\
\text { hubungan seksual }\end{array}$ & $104(86,7 \%)$ & $16(13,3 \%)$ \\
\hline $\begin{array}{l}\text { Infeksi HPV dapat } \\
\text { diobati } \\
\text { antibiotik }\end{array}$ & $74(61,7 \%)$ & $46(38,3 \%)$ \\
\hline $\begin{array}{l}\text { Vaksinasi HPV } \\
\text { dapat mencegah } \\
\text { kanker serviks }\end{array}$ & $119(99,2 \%)$ & $1(0,8 \%)$ \\
\hline $\begin{array}{lr}\text { Vaksin } & \text { HPV } \\
\text { dianjurkan } & \text { pada } \\
\text { wanita dan laki-laki }\end{array}$ & $76(63,3 \%)$ & $44(36,7 \%)$ \\
\hline $\begin{array}{l}\text { Semua tipe HPV } \\
\text { dapat menyebabkan } \\
\text { kanker }\end{array}$ & $65(54,2 \%)$ & $55(45,8 \%)$ \\
\hline
\end{tabular}

Tabel 3. Skor Pengetahuan Responden

\begin{tabular}{ccc}
\hline \hline $\begin{array}{c}\text { Tingkat } \\
\text { Pengetahuan }\end{array}$ & Skor & $\mathrm{n}(\%)$ \\
\hline Rendah & Skor $\leq 2$ & $2(1,7 \%)$ \\
\hline Sedang & Skor $3-4$ & $33(27,5 \%)$ \\
\hline Tinggi & Skor $>4$ & $85(70,9 \%)$ \\
\hline \hline
\end{tabular}

Hasil analisis data menunjukkan bahwa pengetahuan responden cukup baik dengan skor jawaban benar rata-rata sebanyak 5 dari 7 pernyataan. Berdasarkan hasil penelitian yang dilakukan di California Selatan pada 172 responden mengenai persepsi dan pengetahuan mahasiswi tentang HPV dan kanker serviks, sebanyak 68,2\% $(\mathrm{n}=148)$ responden mendapat skor di atas $50 \%$ dan $31,8 \%$ responden mendapat skor kurang dari $50 \%$ dan rata-rata skor pengetahuan adalah 63,69\% (Lopez \& Mcmahan, 2007). Apabila dibandingkan dengan penelitian tersebut, skor rata-rata mahasiswi pada penelitian ini lebih tinggi yaitu $71,4 \%$ dan sebanyak 108 (90\%) responden mendapat skor lebih dari $50 \%$. Dari 7 pernyataan, sebagian besar mahasiswi dapat memahami bahwa vaksinasi HPV dapat mencegah kanker serviks (99,2\%). 
Pengetahuan mahasiswi tentang penyebab kanker serviks (44,2\% menjawab benar) dan tipe HPV penyebab kanker $(54,2 \%$ menjawab benar) terbilang masih rendah sehingga untuk meningkatkan pengetahuan dan kesadaran tentang HPV dan kanker serviks perlu dilakukan pemberian informasi melalui promosi kesehatan.

\section{Teori Health Belief Model}

Tabel 4. Profil Keyakinan terhadap Vaksin HPV berdasarkan teori HBM Susceptibility dan Severity

\begin{tabular}{|c|c|c|c|c|c|}
\hline \multirow{2}{*}{ Pernyataan } & \multicolumn{5}{|c|}{ n(\%) } \\
\hline & SS & $\mathbf{S}$ & $\mathbf{N}$ & TS & STS \\
\hline \multicolumn{6}{|l|}{ Susceptibility } \\
\hline $\begin{array}{c}\text { Jika saya tidak } \\
\text { mendapatkan } \\
\text { vaksin HPV, } \\
\text { saya berisiko } \\
\text { mengalami }\end{array}$ & $7(5.8 \%)$ & $\begin{array}{c}50 \\
(41.7 \%)\end{array}$ & $\begin{array}{c}43 \\
(35.8 \%)\end{array}$ & $\begin{array}{c}18 \\
(15 \%)\end{array}$ & $\begin{array}{c}2 \\
(1.7 \%)\end{array}$ \\
\hline $\begin{array}{l}\text { kanker serviks } \\
\text { di masa depan. }\end{array}$ & & & & & \\
\hline $\begin{array}{l}\text { Saya yakin } \\
\text { pola hidup saya } \\
\text { tidak berisiko } \\
\text { terkena } \\
\text { penyakit }\end{array}$ & $10(8.3 \%)$ & $\begin{array}{c}48 \\
(40 \%)\end{array}$ & $\begin{array}{c}44 \\
(36.7 \%)\end{array}$ & $\begin{array}{c}15 \\
(12.5 \%)\end{array}$ & $\begin{array}{c}3 \\
(2.5 \%)\end{array}$ \\
\hline \multicolumn{6}{|l|}{ kanker serviks. } \\
\hline $\begin{array}{l}\text { Saya yakin } \\
\text { tidak akan }\end{array}$ & $\begin{array}{c}6 \\
(5 \%)\end{array}$ & $\begin{array}{c}27 \\
(22.5 \%)\end{array}$ & $\begin{array}{c}30 \\
(25 \%)\end{array}$ & $\begin{array}{c}51 \\
(42.5 \%)\end{array}$ & $\begin{array}{c}6 \\
(5 \%)\end{array}$ \\
\hline $\begin{array}{l}\text { terkena kanker } \\
\text { serviks JIKA }\end{array}$ & & & & & \\
\hline \multicolumn{6}{|l|}{$\begin{array}{c}\text { keluarga saya } \\
\text { tidak } \\
\text { mempunyai } \\
\text { riwayat kanker. }\end{array}$} \\
\hline \multicolumn{6}{|l|}{ Severity } \\
\hline $\begin{array}{c}\text { Jika saya } \\
\text { mengalami } \\
\text { penyakit }\end{array}$ & $\begin{array}{c}51 \\
(42.5 \%)\end{array}$ & $\begin{array}{c}58 \\
(48.3 \%)\end{array}$ & $\begin{array}{c}9 \\
(7.5 \%)\end{array}$ & $\begin{array}{c}2 \\
(1.7 \%)\end{array}$ & $\begin{array}{c}0 \\
(0 \%)\end{array}$ \\
\hline $\begin{array}{c}\text { kanker serviks, } \\
\text { akan } \\
\text { berdampak } \\
\text { besar dalam } \\
\text { hidup saya. }\end{array}$ & & & & & \\
\hline $\begin{array}{c}\text { Saya yakin } \\
\text { bahwa kanker } \\
\text { serviks sulit } \\
\text { disembuhkan. }\end{array}$ & $\begin{array}{c}21 \\
(17.5 \%)\end{array}$ & $\begin{array}{c}53 \\
(44.2 \%)\end{array}$ & $\begin{array}{c}27 \\
(22.5 \%)\end{array}$ & $\begin{array}{c}18 \\
(15 \%)\end{array}$ & $\begin{array}{c}1 \\
(0.8 \%)\end{array}$ \\
\hline $\begin{array}{c}\text { Saya yakin } \\
\text { bahwa kanker } \\
\text { serviks dapat } \\
\text { menyebabkan } \\
\text { kematian. }\end{array}$ & $\begin{array}{c}39 \\
(32.5 \%)\end{array}$ & $\begin{array}{c}59 \\
(49.2 \%)\end{array}$ & $\begin{array}{c}19 \\
(15.8 \%)\end{array}$ & $\begin{array}{c}3 \\
(2.5 \%)\end{array}$ & $\begin{array}{c}0 \\
(0 \%)\end{array}$ \\
\hline
\end{tabular}

Berdasarkan analisis jawaban dari responden pada Tabel 4. Maka, diperoleh profil keyakinan terhadap vaksin HPV yang dikaitkan dengan teori HBM.

Perceived Susceptibility

Perceived susceptibility atau persepsi kerentanan memiliki persentase rata-rata hasil netral yang paling banyak dibandingkan dengan konstruk lain, yaitu sebesar $32,5 \%$. Hasil penelitian di Surakarta, Jawa Tengah menyatakan adanya hubungan yang signifikan antara perceived susceptibility dengan perilaku vaksinasi HPV dengan kerentanan yang tinggi perilaku melakukan vaksinasi HPV meningkat hingga 72,4\% (Fitriani et al., 2018). Beberapa faktor yang dapat mempengaruhi kerentanan untuk melakukan vaksinasi HPV yaitu keyakinan atas pola hidup yang sudah baik dan tidak memiliki riwayat penyakit keluarga. Selain itu, kerentanan terhadap terjadinya kanker serviks juga dipengaruhi oleh faktor sosio demografi seperti usia dan status sosial ekonomi serta faktor aktivitas seksual yang meliputi berganti-ganti pasangan seks, kurang menjaga kebersihan genital, merokok, riwayat penyakit kelamin, penggunaan pembalut dan pantyliner, dietil-stilbetrol (DES) hingga penggunaan kontrasepsi oral (Ningsih et al., 2017).

\section{Perceived Severity}

Dari profil perceived severity atau persepsi keseriusan, mahasiswi merasa bahwa kanker serviks merupakan penyakit yang berdampak besar dalam hidup sebanyak $109 \quad(90,8 \%)$, sulit disembuhkan sebanyak $74 \quad(61,7 \%)$, bahkan mahasiswi yakin bahwa kanker serviks dapat menyebabkan kematian sebanyak 98 (81,7\%). Hal ini menunjukkan banyak responden merasakan bahwa kanker serviks adalah penyakit yang serius. Hal ini sesuai dengan fakta bahwa kanker serviks dapat menyerang puncak usia produktif perempuan sehingga akan menyebabkan gangguan kualitas hidup secara fisik, kejiwaaan dan kesehatan sosial (Fitriana dan Ambarini, 2012).

Tabel 5. Profil Keyakinan terhadap Vaksin HPV berdasarkan teori HBM Benefit dan Barrier 
Berdasarkan analisis jawaban dari responden pada Tabel 5. Maka, diperoleh profil keyakinan terhadap vaksin HPV yang dikaitkan dengan teori HBM.

\section{Perceived Benefit}

Dari profil perceived benefit atau persepsi manfaat, mahasiswi meyakini bahwa vaksinasi HPV dapat mencegah kanker serviks $(89,2 \%)$, memberikan rasa aman $(71,6 \%)$ dan dapat meningkatkan kualitas hidup (70,9\%). Dari hasil yang diperoleh, banyak responden yang sudah menyadari berbagai manfaat melakukan vaksinasi HPV antara lain dapat mencegah kanker serviks, memberikan rasa aman, dan meningkatkan kualitas hidup. Vaksinasi HPV merupakan upaya pencegahan primer yang diharapkan akan menurunkan terjadinya infeksi HPV risiko tinggi, menurunkan kejadian karsinogenesis kanker serviks dan pada akhirnya menurunkan kejadian kanker serviks uterus (Keputusan Menteri Kesehatan, 2015). Pemberian vaksinasi HPV juga dilaporkan dapat memberi proteksi sebesar 89\% karena mempunyai cross protection dengan tipe lain (Setiawati, 2014).

\section{Perceived Barrier}

Dari perceived barrier atau persepsi hambatan dalam melakukan vaksinasi HPV masih banyak dialami oleh responden seperti harga yang terbilang mahal $(53,4 \%)$ dan kurangnya informasi mengenai tempat vaksinasi HPV $(62,5 \%)$. Data hasil dari hambatan efek samping vaksin mempunyai persentase terbanyak pada pilihan netral $(41,7 \%)$ sehingga menyebabkan bias dan tidak dapat disimpulkan apakah efek samping menjadi hambatan bagi responden untuk melakukan vaksinasi HPV. Hal ini mungkin dapat disebabkan oleh responden yang kurang memahami efek samping dengan tidak membaca keterangan yang tertulis pada kuesioner. Efek samping vaksinasi HPV meliputi memar dibagian suntikan, nyeri kepala dan nyeri otot hingga demam ringan $\left(37,7^{\circ} \mathrm{C}\right)$ maupun sedang $\left(39^{\circ} \mathrm{C}\right)$, reaksi alergi ringan (gatal, mual, biduran), dan reaksi alergi berat seperti kesulitan bernapas (CDC, 2015).

Berdasarkan penelitian yang dilakukan pada siswi kelas X SMA swasta di Kabupaten Badung $(n=408)$, beragam alasan yang menghambat responden untuk melakukan vaksinasi HPV antara lain sebesar $41,6 \%$ responden terhambat karena biaya vaksinasi yang mahal, sebesar $33,1 \%$ responden menjawab karena vaksinasi HPV sulit diperoleh, 30,9\% mengatakan tidak ada dukungan dari orang tua dan $7,0 \%$ mengatakan tidak ada dukungan dari orang terdekat. Terlihat juga bahwa terdapat sebesar $33,1 \%$ responden tidak melakukan vaksinasi HPV dikarenakan responden tidak merasa memiliki resiko sehingga tidak perlu melakukan vaksinasi tersebut (Dethan dan Suariyani, 2017).

\begin{tabular}{|c|c|c|c|c|c|}
\hline \multirow{2}{*}{ Pernyataan } & \multicolumn{5}{|c|}{ n (\%) } \\
\hline & SS & $\mathbf{S}$ & $\mathbf{N}$ & TS & STS \\
\hline \multicolumn{6}{|l|}{ Benefit } \\
\hline $\begin{array}{l}\text { Mendapatkan } \\
\text { vaksin HPV } \\
\text { secara lengkap } \\
\text { akan membantu } \\
\text { saya dalam } \\
\text { mencegah } \\
\text { terkena kanker } \\
\text { serviks }\end{array}$ & $\begin{array}{c}33 \\
(27.5 \%)\end{array}$ & $\begin{array}{c}74 \\
(61.7 \%)\end{array}$ & $\begin{array}{c}12 \\
(10 \%)\end{array}$ & $\begin{array}{c}1 \\
(0.8 \%)\end{array}$ & $\begin{array}{c}0 \\
(0 \%)\end{array}$ \\
\hline $\begin{array}{l}\text { Saya merasa } \\
\text { aman jika telah } \\
\text { melakukan }\end{array}$ & $\begin{array}{c}22 \\
(18.3 \%)\end{array}$ & $\begin{array}{c}64 \\
(53.3 \%)\end{array}$ & $\begin{array}{c}32 \\
(26.7 \%)\end{array}$ & $\begin{array}{c}2 \\
(1.7 \%)\end{array}$ & $\begin{array}{c}0 \\
(0 \%)\end{array}$ \\
\hline $\begin{array}{l}\text { vaksinasi HPV. } \\
\text { Saya yakin bisa } \\
\text { meningkatkan } \\
\text { kualitas hidup }\end{array}$ & $\begin{array}{c}14 \\
(11.7 \%)\end{array}$ & $\begin{array}{c}71 \\
(59.2 \%)\end{array}$ & $\begin{array}{c}32 \\
(26.7 \%)\end{array}$ & $\begin{array}{c}3 \\
(2.5 \%)\end{array}$ & $\begin{array}{c}0 \\
(0 \%)\end{array}$ \\
\hline \multicolumn{6}{|l|}{$\begin{array}{l}\text { APABILA telah } \\
\text { melakukan } \\
\text { vaksinasi HPV. }\end{array}$} \\
\hline \multicolumn{6}{|l|}{ Barrier } \\
\hline $\begin{array}{c}\text { Harga vaksin } \\
\text { mencegah saya } \\
\text { untuk } \\
\text { mendapatkan } \\
\text { vaksin HPV. }\end{array}$ & $\begin{array}{c}17 \\
(14.2 \%)\end{array}$ & $\begin{array}{c}47 \\
(39.2 \%)\end{array}$ & $\begin{array}{c}36 \\
(30 \%)\end{array}$ & $\begin{array}{c}19 \\
(15.8 \%)\end{array}$ & $\begin{array}{c}1 \\
(0.8 \%)\end{array}$ \\
\hline $\begin{array}{c}\text { Efek samping } \\
\text { dari vaksin } \\
\text { mencegah saya } \\
\text { unuk } \\
\text { mendapatkan } \\
\text { vaksin HPV. }\end{array}$ & $\begin{array}{c}5 \\
(4.2 \%)\end{array}$ & $\begin{array}{c}23 \\
(19.2 \%)\end{array}$ & $\begin{array}{c}50 \\
(41.7 \%)\end{array}$ & $\begin{array}{c}38 \\
(31.7 \%)\end{array}$ & $\begin{array}{c}4 \\
(3.3 \%)\end{array}$ \\
\hline $\begin{array}{c}\text { Kurangnya } \\
\text { informasi } \\
\text { mengenai } \\
\text { tempat vaksinasi } \\
\text { HPV menjadi } \\
\text { hambatan saya } \\
\text { untuk } \\
\text { melakukan } \\
\text { vaksinasi. }\end{array}$ & $\begin{array}{c}31 \\
(25.8 \%)\end{array}$ & $\begin{array}{c}44 \\
(36.7 \%)\end{array}$ & $\begin{array}{c}23 \\
(19.2 \%)\end{array}$ & $\begin{array}{c}19 \\
(15.8 \%)\end{array}$ & $\begin{array}{c}3 \\
(2.5 \%)\end{array}$ \\
\hline
\end{tabular}

Tabel 6. Skor Keyakinan terhadap Konstruk HBM

\begin{tabular}{|c|c|c|c|}
\hline \multirow[t]{2}{*}{ Variabel } & \multicolumn{3}{|c|}{ Perilaku Vaksinasi HPV } \\
\hline & Tidak & $\mathrm{Ya}$ & Total \\
\hline & $\mathrm{n}(\%)$ & $\mathrm{n}(\%)$ & $\mathrm{n}(\%)$ \\
\hline \multicolumn{4}{|l|}{ Perceived } \\
\hline Susceptibility & $4(50 \%)$ & $4(50 \%)$ & $8(6,7 \%)$ \\
\hline Rendah $(\leq 6)$ & $38(65,5 \%)$ & $20(34,5 \%)$ & $58(48,3 \%)$ \\
\hline Sedang (7-9) & $35(64,8 \%)$ & $19(35,2 \%)$ & $54(45 \%)$ \\
\hline \multicolumn{4}{|l|}{ Tinggi $(\geq 10)$} \\
\hline \multicolumn{4}{|l|}{ Perceived } \\
\hline Severity & $1(100 \%)$ & 0 & $1(0,8 \%)$ \\
\hline Rendah $(\leq 6)$ & $6(60 \%)$ & $4(40 \%)$ & $10(8,4 \%)$ \\
\hline Sedang (7-9) & $70(64,2 \%)$ & $39(35,8 \%)$ & 109 \\
\hline Tinggi $(\geq 10)$ & & & $(90,8 \%)$ \\
\hline \multicolumn{4}{|l|}{ Perceived } \\
\hline Rendah $(\leq 6)$ & $8(88,9 \%)$ & $1(11,1 \%)$ & $9(7,5 \%)$ \\
\hline Sedang (7-9) & $69(62,1 \%)$ & $42(37,9 \%)$ & 111 \\
\hline Tinggi $(\geq 10)$ & & & $(92,5 \%)$ \\
\hline \multicolumn{4}{|l|}{ Perceived } \\
\hline Barier & $9(32,1 \%)$ & $19(67,9 \%)$ & $28(23,3 \%)$ \\
\hline Rendah $(\leq 6)$ & $52(82,5 \%)$ & $11(17,5 \%)$ & $63(52,5 \%)$ \\
\hline Sedang (7-9) & $16(55,2 \%)$ & $13(44,8 \%)$ & $29(24,2 \%)$ \\
\hline Tinggi $(\geq 10)$ & & & \\
\hline
\end{tabular}

Berdasarkan hasil analisis jawaban responden terhadap kostruk HBM pada Tabel 6 menyatakan bahwa dengan skor keyakinan yang tinggi tidak mempengaruhi niat melakukan vaksinasi HPV. Pada perceived susceptibility didapatkan jumlah responden dengan skor sedang dan tinggi yang hampir sama. Sedangkan pada perceived severity 
dan benefit dengan skor tinggi yang didapat responden diketahui niat untuk melakukan vaksinasi juga lebih tinggi yaitu sebesar $39(35,8 \%)$ responden pada perceived severity memilih untuk vaksinasi HPV dan $42(37,9 \%)$ responden pada perceived benefit memilih untuk vaksinasi HPV. Adanya jawaban netral pada perceived barrier menyebabkan responden dengan nilai sedang sebanyak $52(82,5 \%)$ namun niat untuk melakukan vaksin hanya sebesar $17,5 \%$. Hal ini membuktikan bahwa persepsi ini mengacu pada perasaan seseorang untuk melakukan tindakan kesehatan yang disarankan karena orang tersebut mempertimbangkan keefektifan tindakan terhadap persepsi bahwa hal itu mungkin mahal, berbahaya (misalnya, efek samping), tidak menyenangkan (misalnya menyakitkan), menyita waktu, atau merepotkan. Begitu pula pada hasil penelitian Fitriani et al., 2018 yang menyatakan sebagian besar subyek penelitian yang tidak mendapatkan vaksinasi HPV mengakui bahwa biaya vaksin masih terlalu mahal, takut efek samping, dan juga kurangnya manfaat yang bisa langsung dirasakan. Namun, subyek yang melakukan vaksinasi HPV mengenali bahwa perasaan tersebut bukanlah hambatan bagi mereka.

Tabel 7. Uji Korelasi Konstruk HBM vs Niat Vaksinasi HPV

\begin{tabular}{|c|c|c|c|c|c|}
\hline \multirow[b]{2}{*}{ Variabel } & \multicolumn{3}{|c|}{$\begin{array}{cl}\text { Niat Vaksinasi HPV } \\
\end{array}$} & \multirow[b]{2}{*}{$* \mathbf{R}$} & \multirow[b]{2}{*}{$* \mathbf{P}$} \\
\hline & $\begin{array}{l}\text { Tidak } \\
\mathrm{n}(\%) \\
\end{array}$ & $\begin{array}{c}\mathrm{Ya} \\
\mathrm{n}(\%)\end{array}$ & $\begin{array}{c}\text { Total } \\
\mathrm{n}(\%) \\
\end{array}$ & & \\
\hline $\begin{array}{l}\text { Perceived } \\
\text { Susceptibility } \\
\text { Rendah }(3-9) \\
\text { Tinggi(10-15) }\end{array}$ & $\begin{array}{c}42 \\
(63,6 \%) \\
35 \\
(64,8 \%) \\
\end{array}$ & $\begin{array}{l}24(36,4 \%) \\
19(35,2 \%)\end{array}$ & $\begin{array}{l}66(55 \%) \\
54(45 \%)\end{array}$ & 0,161 & 0,956 \\
\hline $\begin{array}{l}\text { Perceived } \\
\text { Severity } \\
\text { Rendah }(3-9) \\
\text { Tinggi }(10-15)\end{array}$ & $\begin{array}{c}7 \\
(63,6 \%) \\
70 \\
(64,2 \%) \\
\end{array}$ & $\begin{array}{c}4(36,4 \%) \\
39(35,8 \%)\end{array}$ & $\begin{array}{c}11(9,2 \%) \\
109 \\
(90,8 \%)\end{array}$ & 0,151 & 0,947 \\
\hline $\begin{array}{l}\text { Perceived } \\
\text { Benefit } \\
\text { Rendah (3-9) } \\
\text { Tinggi }(10-15)\end{array}$ & $\begin{array}{c}8 \\
(88,9 \%) \\
69 \\
(62,1 \%) \\
\end{array}$ & $\begin{array}{c}1(11,1 \%) \\
42(37,9 \%)\end{array}$ & $\begin{array}{c}9(7,5 \%) \\
111 \\
(92,5 \%)\end{array}$ & 0,228 & 0,363 \\
\hline $\begin{array}{l}\text { Perceived } \\
\text { Barrier } \\
\text { Rendah (3-9) } \\
\text { Tinggi (10-15) }\end{array}$ & $\begin{array}{c}61 \\
(67,0 \%) \\
16 \\
(55,2 \%)\end{array}$ & $\begin{array}{l}30(33,0 \%) \\
13(44,8 \%)\end{array}$ & $\begin{array}{l}91(75,8 \%) \\
29(24,2 \%)\end{array}$ & 0,210 & 0,783 \\
\hline
\end{tabular}

Berdasarkan hasil uji korelasi pada Tabel 7, perceived susceptibility, severity, benefit, dan barrier tidak menunjukkan adanya hubungan pada responden yang berniat atau yang tidak berniat.
Pada penelitian ini, sebesar $64,8 \%$ responden memiliki perceived susceptibility tinggi, namun tidak memiliki niat untuk melakukan vaksinasi HPV. Kerentanan terhadap kanker serviks juga diteliti pada wanita di Maryland Universiy, United States yang diketahui bahwa perceived susceptibility tidak ditemukan berbeda secara signifikan terhadap perilaku vaksinasi. Kerentanan mungkin tidak menjadi variabel utama penerima vaksin di Maryland Universiy untuk suatu pencegahan (Ziemer dan Hoffman, 2013). Persepsi individu bahwa seseorang tidak berisiko merupakan faktor yang menyebabkan wanita usia subur di University of Utah, United States tidak melakukan vaksinasi HPV yang diartikan bahwa bila wanita setia terhadap satu pasangan maka wanita tersebut tidak berisiko tertular kanker serviks (Wilson et al., 2016).

Pada persepsi keparahan kanker serviks, sebesar 64,2\% responden yang memiliki tingkat persepsi keparahan dari kanker serviks percaya bahwa dengan adanya kanker serviks, dapat mempengaruhi kelangsungan hidup, memilih untuk tidak melakukan vaksinasi. Pada penelitian yang dilakukan pada wanita di usia reproduktif di Surakarta, Jawa Tengah, diketahui bahwa ada hubungan statistik signifikan antara persepsi keseriusan dengan perilaku vaksinasi HPV. Sebesar $62,1 \%$ responden yang memiliki tingkat persepsi manfaat tinggi memilih untuk tidak melakukan vaksinasi. Hal ini berbeda dari penelitian yang dilakukan oleh Fitriani et al., 2018 yang menyatakan bahwa persepsi manfaat yang besar akan meningkatkan perilaku vaksinasi HPV daripada persepsi HPV yang kecil.

Pada perceived barier tidak menunjukkan perbedaan signifikan responden yang berniat atau yang tidak berniat. Hal ini dapat diartikan dengan tingginya persepsi hambatan terhadap kanker serviks tidak mempengaruhi niat seseorang untuk melakukan vaksinasi HPV. Berbeda halnya dengan penelitian Fitriani et al., (2018) yang menyatakan hubungan yang signifikan antara persepsi hambatan dengan perilaku vaksinasi HPV dengan hasil mayoritas subjek penelitian tidak melakukan vaksinasi HPV karena harga yang mahal, ketakutan akan efek samping, dan kurangnya manfaat yang cepat dirasakan. Berdasarkan hasil analisis jawaban responden pada perceived barrier, sebanyak 61 $(67,0 \%)$ responden yang memiliki persepsi hambatan rendah memilih untuk tidak melakukan vaksinasi. Penelitian yang dilakukan pada wanita di Maryland Universiy, United States diketahui bahwa persepsi hambatan dapat berkurang bila lingkungan sekitarnya mengetahui akan informasi vaksinasi (Ziemer dan Hoffman, 2013). 
Tabel 8. Uji Korelasi Pengetahuan, Rentang Pendapatam, dan Dukungan Keluarga dengan Niat Vaksinasi HPV

\begin{tabular}{|c|c|c|c|c|c|}
\hline \multirow[b]{2}{*}{ Variabel } & \multicolumn{3}{|c|}{ Niat Vaksinasi HPV } & \multirow[b]{2}{*}{$* \mathbf{R}$} & \multirow[b]{2}{*}{$* \mathbf{P}$} \\
\hline & $\begin{array}{l}\text { Tidak } \\
\mathrm{n}(\%) \\
\end{array}$ & $\begin{array}{c}\mathrm{Ya} \\
\mathrm{n}(\%)\end{array}$ & $\begin{array}{c}\text { Total } \\
\mathrm{n}(\%) \\
\end{array}$ & & \\
\hline $\begin{array}{l}\text { 1.Pengetahuan } \\
\text { Rendah }(\leq 2) \\
\text { Sedang }(3-4) \\
\text { Tinggi }(>4)\end{array}$ & $\begin{array}{l}1(50 \%) \\
20(60,6 \%) \\
56(65,9 \%)\end{array}$ & $\begin{array}{l}1(50 \%) \\
13(39,4 \%) \\
29(34,1 \%)\end{array}$ & $\begin{array}{l}2(1,7 \%) \\
33(27,5 \%) \\
85(70,8 \%)\end{array}$ & 0.093 & 0.726 \\
\hline $\begin{array}{l}\text { 2.Rentang } \\
\text { Pendapatan } \\
\text { Rendah } \\
(<5.00 .000) \\
\text { Sedang } \\
(500.000- \\
5.000 .000) \\
\text { Tinggi } \\
(>5.000 .000)\end{array}$ & $\begin{array}{l}2(50 \%) \\
51(64,5 \%) \\
24(64,9 \%)\end{array}$ & $\begin{array}{l}2(50 \%) \\
28(35,5 \%) \\
13(35,1 \%)\end{array}$ & $\begin{array}{l}4(3,3 \%) \\
79(65,8 \%) \\
37(30,9 \%)\end{array}$ & 0.028 & 0.577 \\
\hline $\begin{array}{l}\text { 3.Dukungan } \\
\text { Keluarga } \\
\text { Ada } \\
\text { Tidak Ada }\end{array}$ & $\begin{array}{l}53(57,0 \%) \\
24(89,0 \%)\end{array}$ & $\begin{array}{l}40(43,0 \%) \\
3(11,0 \%)\end{array}$ & $\begin{array}{l}93(77,5 \%) \\
27(22,5 \%)\end{array}$ & 0.278 & 0.002 \\
\hline
\end{tabular}

Hasil penelitian pada Tabel 8 menunjukkan terdapat hubungan yang signifikan antara dukungan keluarga dengan niat melakukan vaksinasi HPV. Berdasarkan hasil analisis jawaban responden pada konstruk dukungan keluarga, sebesar 77,5 \% ada dukungan keluarga dan $22,5 \%$ yang tidak ada dukungan keluarga, namun hanya 35,8\% yang mempunyai kemauan untuk melakukan vaksinasi HPV. Responden tidak melakukan vaksinasi HPV karena harga yang mahal, ketakutan akan efek samping, dan kurangnya manfaat yang cepat dirasakan. Berbeda dengan penelitian yang dilakukan di Surakarta, Jawa Tengah yang menyatakan dukungan keluarga yang kuat akan meningkatkan perilaku vaksinasi HPV sebesar 6,86 kali dari pada dukungan keluarga yang lemah. Peran keluarga sangat kuat dalam memberikan pemeriksaan kesehatan sehingga sangat mempengaruhi status kesehatannya. Keluarga merupakan orang terdekat dalam berinteraksi dan dalam mengambil keputusan terutama dalam menentukan kemana akan mencari pengobatan (Fitriani et al., 2018)

\section{KESIMPULAN}

Pengetahuan mahasiswi tentang kanker serviks dan vaksinasi HPV tidak mempengaruhi niat untuk melakukan vaksinasi HPV. Namun, adanya dukungan keluarga menunjukkan adanya hubungan dengan niat melakukan vaksinasi HPV. Dalam hal ini, diperlukan suatu upaya peningkatan program pemerintah dan fasilitas kesehatan yang mendukung sosialisasi tentang kanker serviks dan vaksinasi HPV pada mahasiswi, baik secara langsung maupun melalui media cetak dan elektronik karena dengan pengetahuan dan keyakinan yang baik diharapkan niat melakukan vaksinasi HPV juga akan semakin meningkat.

\section{PUSTAKA}

Agosti, J.M., \& Goldie, S.J. 2007, 'Introducing HPV vaccine in developing countries--key challenges and issues', $N$ Engl J Med, pp. 1908-1910.

Brewer, N.T., \& Fazekas, K.I. 2007, 'Predictors of HPV vaccine acceptability: A theory-informed, systematic review', Preventive Medicine, 45(23), 107-114.

CDC (Center of Disease Control). 2015. Human Papillomavirus (HPV) Vaccine Safety. <https://www.cdc.gov/vaccinesafety/vaccines/ hpv-vaccine.html >. [Accessed 09 April 2019].

Dethan, C.M., \& Suariyani, N.L.P. 2017, 'Pengetahuan Dan Sikap Tentang Perilaku Vaksinasi Hpv Pada Siswi Sma Swasta', Media Kesehatan Masyarakat Indonesia, 13(2), 167175.

Ekowati, D., Udiyono, A., Martini, A., \& Mateus, S. 2017, 'Hubungan Pengetahuan dengan Persepsi Mahasiswi dalam Penerimaan Vaksinasi HPV sebagai Upaya Pencegahan Kanker Serviks', Jurnal Kesehatan Masyarakat, 5(4), 334-341.

Fitriana, N.A., \& Ambarini, T.K. 2012, 'Kualitas Hidup Pada Penderita Kanker Serviks Yang Menjalani Pengobatan Radioterapi', Jurnal Psikologi Klinis Dan Kesehatan Mental, 1(2), 123-129.

Fitriani, Y., Mudigdo, A., \& Andriani, R.B. 2018, 'Health Belief Model on the Determinants of Human Papilloma Virus Vaccination in Women of Reproductive Age in Surakarta , Central Java', Journal of Health Promotion and Behavior, 3(1): 16-26

Hsu, Y.Y., Fetzer, S.J., Hsu, K.F., Chang, Y.Y., Huang, C.P., \& Chou, C.Y. 2009, 'Intention to obtain human papillomavirus vaccination among taiwanese undergraduate women', Sexually Transmitted Diseases, 36(11), 686692.

ICO Information Centre on HPV and Cancer (HPV Information Centre). 2018. Human Papilloma virus and Related Diseases in Indonesia. WHO summary report.

Kementerian Kesehatan RI Pusat Data dan Informasi Kesehatan. 2015, 'Stop Kanker', Infodatin-Kanker

Keputusan Menteri Kesehatan RI. 2015, 'Keputusan Menteri Kesehatan RI No. 34 Tahun 2015 Tentang Pedoman Teknis Pengendalian Kanker Payudara dan Kanker Leher Rahim', Jakarta. 
Lopez, R., \& Mcmahan, S. 2007, 'College Women's Perception and Knowledge of Human Papillomavirus (HPV) and Cervical Cancer', Californian Journal of Health Promotion, 5(3), 12-25.

Marlina., Putra., Sopianti., Arfiandi., Aldi, Y., Andani, E., Selpia, D., Gulyla, D., \& Djamaan, A. 2016, 'Identifikasi Type Human Papillomavirus (HPV) pada Penderita Kanker Serviks', Jurnal Sains Farmasi dan Klinis, 3(1), 54-63.

Ningsih, D.P.S., Pramono, D., \& Nurdiati, D.S. 2017, 'Faktor-Faktor yang Berhubungan dengan Kejadian Kanker Serviks di RSUP Dr. Sardjito Yogyakarta', Berita Kedokteran Masyarakat.

Nurlaila., Shoufiah, R., \& Hazanah, S. 2016, 'Faktor-Faktor yang Berhubungan dengan Prilaku Melakukan Vaksin Kanker Serviks', Mahakam Midwifery Journal, 1(2), 96-105.

Patel, D.A., Zochowski, M., Peterman, S., Dempsey, A.F., \& Dalton, V.K. 2012, 'Human Papillomavirus Vaccine Intent and Uptake Among Female College Students', Journal of American College Health, Vol. 60, No. 2.

Radji, M. 2009, 'Vaksin Kanker', Majalah Ilmu Kefarmasian, 4(3), 109-118.

Sari, A. P., \& Syahrul, F. 2014, 'Faktor yang Berhubungan dengan Tindakan Vaksinasi HPV pada Wanita Usia Dewasa', Jurnal Berkala Epidemologi, 2(3), 321-330.

Setiawati, D. 2014, 'Human Papilloma Virus Dan Kanker Serviks', Public Health Science, 450459.
Setiyaningsih, R., Tamtono, D., \& Suryani, N. 2016, 'Health Belief Model: Determinants of Hypertension Prevention Behavior in Adults at Community Health Center, Sukoharjo, Central Java', Journal of Promotion and Behavior, 1, 161-171.

Wals, C.D., Gera, A., Shah, M., Sharma, A., Powell, J.E., \& Wilsone, S. 2008, 'Public knowledge and attitudes towards Human Papilloma Virus (HPV) vaccination', BMC Public Health.

WHO (World Health Organization). 2017. HPV Vaccine Communication 2016 Update. FAQ [Accessed 09 April 2019].

WHO (World Health Organization). 2016. Human Papilloma Virus (HPV) causes Cervical Cancer. Annex 4 [Accessed 09 April 2019].

Wilson, A.R., Hashibe, M., Bodson, J., Gren, L. H., Taylor, B.A., Greenwood, J., \& Kepka, D. 2016, 'Factors related to HPV vaccine uptake and 3-dose completion among women in a low vaccination region of the USA: An observational study', BMC Women's Health, 16(1), 1-9.

Yayasan Kanker Indonesia. 2017, 'Melantun Kebersamaan Berantas Kanker', Harpa, pp.16.

Ziemer, K.S., \& Hoffman, M.A. 2013, 'Beliefs and attitudes regarding human papillomavirus vaccination among college-age women', Journal of Health Psychology, 18(10), 1360 1370. 